\section{Goat grazing as a wildfire prevention tool: a basic review}

\author{
Raffella Lovreglio $^{(1)}$, Ouahiba Meddour-Sahar ${ }^{(2)}$, Vittorio Leone ${ }^{(3)}$
}

Fuel treatments aimed at reducing both horizontal and vertical continuity in fuels are of paramount importance as a prevention measure against fire propagation. Possible techniques include pruning, thinning (mainly low thinning), mastication, prescribed burning, and prescribed (or targeted) grazing. Their main target is crown fire avoidance by treating surface fuels and promoting low density and vertically discontinuous stands, thus eliminating fuel ladders. Grazing is an effective, nearly carbon-neutral weed control technique which is cost-effective, nontoxic, and nonpolluting. Goat grazing is a very interesting solution: if confined by a metallic or electrified fence within a restricted pen, with a rather high density, goats browse the available foliage and twigs from all woody plants as well as all herbaceous vegetation. They can feed on a variety of shrubs, some of which are useless for other domestic species, and are therefore the best adapted for the consumption of all the Mediterranean shrubs which represent the fuel ladder. The appropriate choice of season of grazing, type of plant species and type and amount of biomass to be eliminated, livestock density, social structure of the herd, grazing time per day, type of fencing, and size of pens define the prescribed grazing system.

Keywords: Fire Prevention, Fuel Treatment, Goat, Grazing, Prevention, Prescribed Grazing, Targeted Grazing

\section{Introduction}

The general response of most countries to the problem of an increasing number of fires and burned areas has generally been to strengthen fire suppression capacity (Costa Alcubierre et al. 2011). France, Greece, Italy, Spain and Portugal spend a total of 2500 million Euros annually in the fight against forest fires, $60 \%$ of which allocated to cover costs related to suppressing fires, while only $40 \%$ is invested in activities targeted to prevention (EFIMED 2012).

(1) Department of Agriculture, University of Sassari, v. Cristoforo Colombo 1, I-08100 Nuoro (Italy); (2) Department of Agricultural Sciences, University Mouloud Mammeri, Box 17 RP, 15000 Tizi Ouzou (Algeria); (3) Department of Crop Systems, Forestry and Environmental Sciences, University of Basilicata, viale dell' Ateneo Lucano 10, I85100 Potenza (Italy)

\section{@ Raffella Lovreglio (rlovreglio@uniss.it)}

Received: Aug 25, 2013 - Accepted: Nov 18, 2013

Citation: Lovreglio R, Meddour-Sahar O, Leone V, 2014. Goat grazing as a wildfire prevention tool: a basic review. iForest 7: 260-268 [online 2014-03-26] URL: http:// www.sisef.it/iforest/contents/?id=ifor1112007

Communicated by: Raffaele Lafortezza
Despite the high investment to improve fire suppression resources, mainly through expenditure on important aerial fleets, such as in Spain, Greece or Italy, the phenomenon continues to be characterized by an aggressive trend, with a progressively reduced interval between dramatic years.

Wildfires occurring during prolonged and for Portugal, 2006 for Spain, 2007 for Algeria, Italy, Spain and Portugal, 2010 for Russia, 2012 for all the Mediterranean countries including Algeria) demonstrate that a different approach must be considered for tackling the problem of forest fires. This means a shift from the short term policy, which is mainly based on huge investments for suppression measures, to a long term preventive policy (Birot 2009, Montiel \& Herrero 2010).

The key purpose of fire prevention measures is to reduce the number of fires through hazard reduction, education, and law enforcement. Improving prevention strategies seems mandatory if a further reduction in the mean yearly burnt area is to be pursued (Ruiz-Mirazo 2011).

\section{Fuel treatment and wildfire minimization}

An appropriate approach to wildfire prevention must be aimed at both lessening the possibility of a fire occurring and minimizing its spread should one occur. This can be severe heat waves (such as in 2003 and 2005 achieved through fuel treatments for biomass reduction, which are paramount to wildfire abatement (Omi \& Martinson 2002). To reduce fire damages, an infrastructure of roads and water supply should be constructed, firebreaks and fire detection systems established, an immediate and efficient intervention of ground crews ensured, but above all, fuel treatments should be timely executed (Leone et al. 2000).

Fuel treatments are a key factor to decreasing wildfire risk (Omi \& Joyce 2003): they target different fuel components in order to achieve both forest structures and fuel characteristics which are able to reduce the likelihood of fire spread.

Fuel treatments are mainly aimed at eliminating the vertical and horizontal continuity of fuels, in order to disrupt the vertical progression of fire (passage from surface fuels to ladder fuels to canopy fuels), and its horizontal progression, especially from crown to crown (Scott \& Reinhardt 2001, Graham et al. 2004).

Activities aimed at reducing surface fuels (low vegetation, woody fuel, shrub layer) decrease the chances of surface fires igniting ladder fuels and canopy fuels (Pollet \& Omi 2002, Fernandes \& Botelho 2003).

The range of possible treatments to modify forest fuels is rather wide, varying from pruning (Leone 2002) to thinning, to mechanical thinning, to fuel mastication (Harrington 2012) to prescribed fire (Leone et al. 1999, Fernandes \& Botelho 2003, Molina et al. 2010, Rego \& Montiel 2010, Ascoli et al. 2012 ) to grazing (Hart 2001, Ruiz-Mirazo et al. 2009, Ruiz-Mirazo 2011, Mancilla-Leytón \& Martín Vicente 2012).

As an alternative to some techniques, a few of which are often perceived as aggressive according to public opinion - such as prescribed fire (Knapp et al. 2009, Vélez 2010) or herbicides - the use of grazing animals could be an efficient method for controlling shrub encroachment and reducing the risk of fire through the elimination of dangerous fuel ladders, as represented by the continuity of grasses and shrubs which enable rapid fire propagation and which permit the transition from high intensity running fires to crown fires (Pollet \& Omi 2002, Fernandes \& Botelho 2003).

All these practices can collectively be targeted as "preventive silviculture"; their main target is crown fire avoidance by treating surface fuels and promoting low density and vertically discontinuous stands (Omi \& Joyce 2003); this also helps to modify fire behavior sufficiently so that some wildfires can be more easily suppressed (Graham et al. 2004). Preventive silviculture manages Mediterranean forests by enhancing their capacity to protect themselves from fires by "creating discontinuities, avoiding very extensi- 


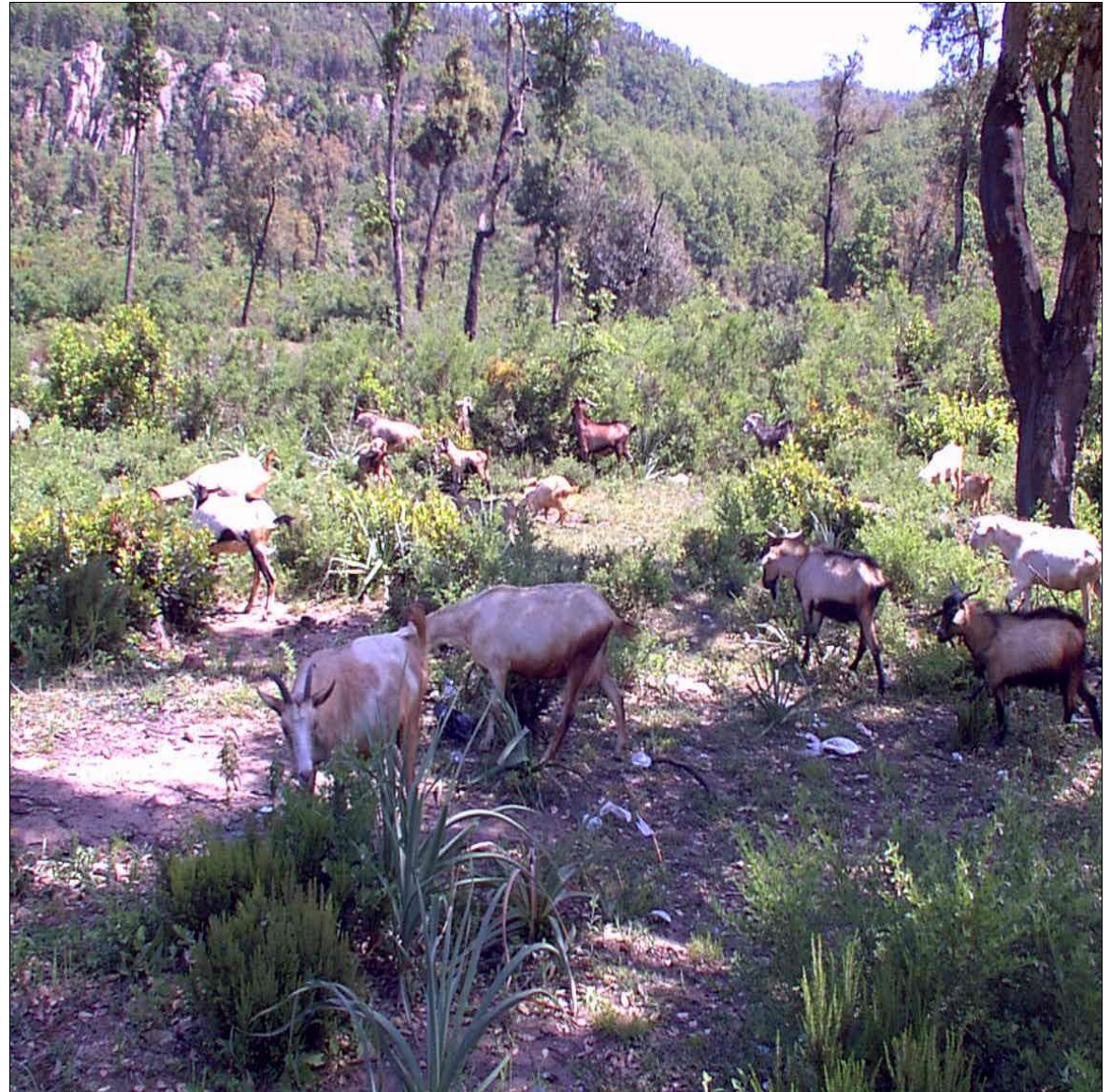

Fig. 1 - A herd of goats freely browsing in a public forest in the Tizi-Ouzou wilaya (Algeria). Trees in the background are badly pollarded for fodder. The presence of geophytes (mainly Asphodelus microcarpus Salzm. \& Viv.) is an indicator of incipient overgrazing pressure on the ecosystem.

ve, monospecific surface areas and creating a patchwork of different inflammability levels that disturb the fire" (Vélez 1990).

The purpose of this article is to emphasize the importance and the role of grazing, mainly by goats, as a prevention tool against wildfires. Goats can help to mitigate the devastation caused by wildfires by consuming fuels with their specific grazing/browsing habits and thus reducing horizontal and vertical continuity of fuels.

\section{Grazing problems}

In the Mediterranean countries grazing has generally been perceived as negative due to experiences of frequent overgrazing and the use of fire for pasture renewal, both of which can cause the onset of desertification. The combination of wildfires and overgrazing is the main cause of rangeland degradation and desertification in Mediterranean European and in most M.E.N.A. (Middle East and North Africa) countries. On the contrary, if properly managed, grazing can play a positive role in fire prevention while preserving species diversity through the replication of the ecological effects of the wild relatives of livestock (Mancilla-Leytón \& Martín Vicente 2012); for this reason it is less likely to elicit a negative public response than the use of prescribed burning, herbicides or thinning.

Grazing is probably the most ecologically sound technique for creating discontinuities rupting fuel ladders. For this reason it is officially considered as a wildfire prevention tool in many countries such as Italy (article 3 of Law 47/1975, now repealed; many regional laws also include grazing by cattle, sheep and pig as appropriate preventive measures).

As a matter-of-fact, until relatively recent times grazing by domestic animals was considered among the major causes of the destruction of the Mediterranean forests, with goats being singled out for their predilection for woody forage (Dimanche \& Coudour 2005). Fuel reduction via prescribed herbivory has now become an acceptable and generalized tool, although as little as 15 to 20 years ago the use of livestock was not officially considered an appropriate tool for fuel in fuels, mainly at the shrubby layer, and dis- reduction (e.g., Pittroff et al. 2006 for California).

The goat is the most suitable species for this purpose because of its browsing ability. On the other hand, in the Mediterranean countries the goat has always been considered a detrimental species, negatively called the "razor of the globe" by Cavara (1914) who coined this image to indicate that goats are destroyers of forests, since they can easily climb young trees and eat all the leaves from branches, or eat all the leaves off seedlings.

A similar image of the "razor of the forests" was adopted by von Mayddel (1980a, 1980b) who considered goats responsible for damage and degradation of established plants as well as for the destruction of regeneration (Moser 2006).

In the early XIX century some European authors (Beatson 1810, Guatieri 1816) provided their own so-called evidence of the negative role of goats, and even accused them of producing environmental catastrophes and evil consequences. This popular assumption has been very hard to dispel (Messines 1952, Seigue 1985, Cans 1999). The controversy surrounding the goat is associated with several interactions with the environment and alleged resource degradation (Fig. 1). Such criticisms are not unique, and can apply to other herbivores, but with goats the allegations are more severe because of their unique mouth parts, selection of feeds, ability to adapt to varying forage quality, their capacity to use coarse grazing and shrubs to their advantage (Devendra 1999) and their ability to use forage resources that cannot be utilized by other ungulates such as sheep or cattle (Nastis 1997).

It is often argued that grazing, with goats as the main catastrophic agents, has been a major contributor to deforestation, perhaps even more so than agricultural clearances (Papanastasis 1986, 2004, Harris 2007, 2012).

More likely, because goats are often among the last species able to feed on poor range condition, they are frequently blamed for the damage done by many decades of abuse by other classes of livestock (Green \& Newell 1982, Papanastasis 2000).

The damaging effect of overgrazing may actually be evident in forests with relatively closed crowns and lack of understorey shrubby vegetation, where goats are forced to browse tree seedlings, young trees or branches of the older trees, thus preventing the regeneration of the forest while at the same time trampling the forest floor and its soil (Papanastasis 1986, Lipson et al. 2011).

Environmental degradation is also associated with the ownership of goats by landless pastoralists and transhumant who live in poverty and are able to survive only because of the goats. Such situations are not uncom- 
mon, especially in the more marginal areas of Asia (e.g., Pakistan, India and China), Africa (e.g., Tanzania and Sudan) and Latin America (e.g., Mexico and Peru - Devendra 1999).

Only in recent times has it been realized that goats are not the real culprits but the continuous, uncontrolled overgrazing for which humans are responsible. A threat to forests comes therefore from irrational and uncontrolled goat grazing (Devendra 1999): it is the mismanagement of goats, rather than their mere presence, that has resulted in damage to Mediterranean forests in the past (Papanastasis 1986, 2004, Siddle 2009).

\section{Goat feeding habits}

Goats exhibit very peculiar feeding habits: their nimble lips and very prehensile tongue permits them to graze on very short grass and to browse on foliage not normally eaten by other domestic livestock, which all combines in an excellent nutrient conversion efficiency for the production of milk (about $45 \%$ - Hart 2001, Georgoudis et al. 2005).

Goats are facultative browsers; they prefer to feed at eye level and upward and then feed on forage from the top of the plant down (Hagstrom et al. 1993, Hutchens 2003) They move freely from plant to plant, removing foliage from select portions of plants. Foliage meals are dictated by quality factors that ensure adequate protein and energy levels. Unlike larger ruminants, there is little fouling or treading of forage (Hutchens 2003).

Goats are often considered to prefer feeding more on shrubs than on grass; they really take a wider variety of plants than other classes of livestock but selectively feed if there is a choice (Green \& Newell 1982, Walker 1994).

Goats feed on a variety of shrubs, some of which are useless for other domestic species, exhibiting a relevant capacity for transforming otherwise useless crude fiber into noble proteins; they are therefore the best adapted species for the consumption of all Mediterranean shrubs (Green \& Newell 1982), providing for an exception of those with high aromatic oil content which are less palatable (Rosmarinus officinalis, Lavandula stoechas, etc. - Mancilla-Leytón \& Martín Vicente 2012). Because of their unusual preferences for the leaves and terminal twigs of woody plants, goats have been exploited as an alternative to herbicides and mechanical cutting against encroaching herbaceous weed and brush species, provided the targeted plants are palatable.

Thanks to their inquisitive nature and tolerance of high tannin material, goats may eat unpalatable weeds and wild shrubs that may be poisonous, but they are often not affected by poisonous compounds or anti-nutritional factors if a sufficient number of other plant species are available. Because goats prefer to consume a very varied diet, the detrimental effects of poisonous compounds found in certain plants can be diluted (Luginbuhl 2000).

The propensity of goats to stretch upwards on their hind legs allows them to commonly browse up to a height of 2 meters in areas where trees and hanging vines are present (Lu 1988). Reports that browsing goats are able to reduce tree growth and slow down woodland expansion in aspen stands, until individuals reach an escape size of $1.5 \mathrm{~m}$ in height (Ascoli et al. 2013), is confirmed by the findings of other authors (Du Plessis et al. 2004 for eastern Cap Region in South Africa, Foroughbakhch et al. 2013 for Mexico).

The types of vegetation present influence the foraging position or posture of goats, most notably the use of a bipedal stance and aerial positions. Goats will only use a bipedal stance if trees are present and will only adopt aerial foraging positions if the trees present are climbable (Goetsch et al. 2009).

Here stays the goat's main role in wildfire prevention, as they easily consume grasses or forbs before they are classified as the $1 \mathrm{~h}$ and 10h time-lag (a fuel's time-lag is proportional to its diameter and is loosely defined as the time it takes a fuel particle to reach $2 / 3$ 's of its way to equilibrium with its local environment) dead fuel categories described in the literature (Deeming et al. 1972). In other words, goats reduce the availability of dead fuels with a diameter of $<2.54 \mathrm{~cm}$ and the availability of small live fuels (terminal twigs of woody plants such as shrubs and trees), both of which are the main propagators of fires as components of the lower layer of the fuel ladder. The grazing of goats can impact the amount and arrangement of these fuels by ingestion or trampling (Nader et al. 2007).

Grazing at moderate levels has been shown to change wildfire behavior, by slowing its spread, shortening flame length, and reducing fire intensity, although it does not significantly reduce the risk of fire ignition (SRCD 2006). In the vicinity of urbanized areas, grazing can prevent or minimize expansion of shrublands which have much greater fuel loading and pose greater fire hazard than grasslands (SRCD 2006).

Grazing can directly reduce the frequency and intensity of fire by removing fine fuels and amplifying the heterogeneity of fuel continuity, and indirectly by causing a shift in plant community composition to less-productive and more-ephemeral species (Fuhlendorf et al. 2008).

In Mediterranean areas, where shrubland often prevails, co-grazing with sheep, cattle and horses, which have mainly grazing habits, could greatly improve grazing of grass thus further reducing fuel load. Since goats, cattle, and sheep prefer different forages, in many pasture situations these species do not compete for the same food (Coffey et al. 2004).

In some cases, the integration of different treatments represents the best strategy. Livestock cannot effectively control mature brush plants that either grow higher than the animals can effectively graze or which have large diameter limbs. As a solution, underburning and/or cutting can be used to eliminate the large-diameter, 100-hour brush fuels, and grazing can be used as a follow up treatment for controlling resprouting species or shifting the species composition to herbaceous plant fuel material (Nader et al. 2007).

The goat has a strong ability to adapt its feeding behavior to the chemical characteristics of food: several studies report selection by goats between diverse plant species, or between individuals of the same plant species according to nutritional quality or the concentration of chemical defenses (Baraza et al. 2009).

Under natural conditions, goats range over a large area, grazing and browsing selectively. Under confined conditions, however, goats will become heavy browsers of trees and shrubs, and less discriminating in their grazing habits, due to the reduced supply of available herbage (Haenlein et al. 1992).

Goats are not pure browsers: the yearly diet of goats is very variable, as an average about 60 percent shrubs, 30 percent grass and 10 percent forbs (Papanastasis 1986) and almost always contains high proportions of lignified components whenever woody species are presents within the pasture, with a wide range of percentage (62-94\% - Nastis 1997).

Lopez-Trujillo \& Garcia-Elizondo (1995) observed that grasses are selected in a low proportion by goats, even in shrubland reseeded with grass. Papachristou (1997) reported a greater rate of biting by goats when available forage was primarily browse vs. non-browse plant species; Nastis \& Nolan (1997) reported that goat diet under different brush cover was mainly based on browsing $(53-65.6 \%)$ followed by grass $(13.1-22 \%)$ and forbs (16.5-20.3\%).

\section{Goat and fuel break management: first experiments}

If confined behind a strong fence, goats browse all the available foliage including all woody plants as well as all herbaceous vegetation (Green \& Newell 1982); this is the basis for the use of goats as a brush clearing tool for the construction of firebreaks (Blanchemain 1981, Bonnier 1981, Calabri 1981, Thirgood 1981).

In Europe the first experiment of controlled grazing for a brush clearing action dates to the '80s in France, where the Forestry Services of Gard wanted to clear a space to serve as a fire-break. A local goat-breeder pro- 
posed to clear the area using his goat herd at a considerably lower price than a traditional land-clearing team.

The area was divided into pens of $0.5-1$ ha, each enclosed by metal fences. The pens were opened one after another, with a stocking density (number of animals per unit area of land at any one point in time; can be expressed as animal units/ha) of 100-200 animals per ha. The goats were allowed into the pens for only 4-6 hours a day. In six months a firebreak of $100 \times 1000$ meters was created. The goats ate $2300 \mathrm{~kg}$ of edible dry matter per ha out of the available $2900 \mathrm{~kg}$, getting $60-75 \%$ of their food requirements by grazing and an increase of up to 10 percent of their live weight per month (Papanastasis 1986).

Further experiments were carried out in Languedoc Roussillon region (1985-2005) on a total area of 27049 ha but the area reduced to a few tens of hectares in 2005 due to budgetary problems (Dimanche \& Coudour 2005).

In Spain, farmers that take part in wildfire prevention programs make their livestock graze intensively in the fuel break areas defined by Forest Services. In exchange, they receive money and/or in-kind remuneration. In Comunitat Valenciana (eastern Spain), a payment of $€ 22 \mathrm{ha}^{-1} \mathrm{yr}^{-1}$ is given to farmers who concentrate their livestock in fuel breaks for a minimum of 130 days. A minimum stocking rate (number of animals per unit area of land over a specified period of time; can be expressed as AUMs/ha - differs from Stocking density by incorporation of time) of one cow, three goats or five sheep per hectare must be maintained; the payment can be increased by some $€ 20-40 \mathrm{ha}^{-1} \mathrm{yr}^{-1}$ if water or a fence are necessary (Ruiz-Mirazo \& Robles 2012).

Similar programs are currently under way in Aragon (3500 hectares of firebreaks) and Andalucía, where the payments per hectare currently range from $€ 42$ to 90 , depending on the grazing difficulty (steepness, type of vegetation and distance to animal housing Ruiz-Mirazo et al. 2009).

The reduction of shrubs by grazing goats intensively within the firebreaks is less costly than other alternative treatments; in addition, the presence of goatherd and dogs constitutes a deterrent to arsonists and ensures early detection (Ruiz-Mirazo et al. 2009). We have no knowledge of similar projects in other countries of the EU, where goat grazing for wildfire prevention purposes is still in an experimental phase (Xanthopoulos et al. 2006).

On the contrary, in the USA, where goats have been used for vegetation management for over a hundred years (Hart 2001), their use in wildfire prevention has been considered a relative success, since they are environmentally friendly and the most cost-ef- fective, nontoxic, nonpolluting solution available.

The use of goats herds is documented in US military camps, such as Camp William (Utah National Guard training field), where no prescribed burning nor herbicides can be employed (Cabrero 2009, Mendenhall 2004), and in the town of Oakland where a budget of 1750000 US\$ is allocated to wildfire prevention using goats (Voth 2009). Los Angeles, Laguna Beach and the Scripps Ranch community of San Diego have also brought the animals in to clear overgrown areas and assist with wildfire prevention (Burgess 2009).

Intensive grazing at the urban interface can create effective firebreaks, as was accomplished near Carson City, Nevada. A fenced corridor around the city was grazed resulting in the removal of 71 to $83 \%$ of fine fuels (Taylor 2006).

In hills around Menlo Park, Oakland, Los Altos, and Berkeley, California, goats have reduced fuel loads in areas too steep for manual labor or mowers. They remove vegetation without disturbing roots or facilitating erosion (Taylor 2006).

More recently, the use of goat grazing is reported throughout other areas of the USA (e.g., Atlanta, Chicago and San Francisco airports; Auburn, CA; Boise, ID; Laguna Beach, CA; Santa Barbara, CA). Goat-powered fuel reduction costs between US\$ 400-500 per acre $\left(4046.85 \mathrm{~m}^{2}\right.$ equivalent to about $40 \%$ of one hectare), nearly one-third of the cost of more labor-intensive methods of brush clearing (USDA 2013). Domestic livestock grazing (without further details about species) is also a prevention measure officially mentioned within the Catastrophic Wildfire Prevention Act, S.14799, 113th Congress, re-introduced 08.01 .2013 by the USA Congress (Govtrack US 2013).

Probably the most popular example of wildfire prevention by goats is by Google, in their headquarters of Mountain View campus, in west California; the success of such a low-tech "green mowing" initiative resonates well with the well-publicized global ideal of carbon footprint reduction, underlining that goats are an effective method of nearly carbon-neutral weed control. Since 2009, the presence of 200 goats with their kids and a goat herder, helped by a nice Border collie, delight Google people and public opinion, for goats in many people's eyes are more pleasing to watch than lawn mowers (AFP 2009, Burgess 2009, Kazuki 2009).

Goats have also got the green lights from PETA (People for the Ethical Treatment of Animals) which has hired goat to mow its lawn (Kazuki 2009).

In Europe, an interesting study case is Matadepera, in the Barcelona Metropolitan Region, where a flock of 200 goats and sheep is being used as a prevention tool by the muni- cipality to control sprouting and to maintain a low fuel load within the coppiced stands (Otero 2010) at a yearly cost of $€ 20,000$.

\section{Use of goats for wildfire prevention}

For wildfire prevention purposes goats cannot merely be put out to eat a plant: the proper choice of season of grazing, livestock density, social structure of herd, grazing time per day, type of fencing, size of pens define an appropriate prescribed grazing system, in strict analogy with prescribed burning (Taylor 2006).

Prescribed grazing, prescribed herbivory (Pittroff et al. 2006) or targeted grazing can be defined as the application of a specific kind of livestock at a determined season, duration, and intensity to accomplish defined vegetation or landscape goals (Launchbaugh \& Walker 2006).

Grazing is a complex tool with many plant and animal variables, including: (I) the species of livestock grazed (cattle, sheep, goats, sometimes horses or a combination); (ii) the animals' previous grazing experience (which can affect their preferences for certain plants); (iii) time of year as it relates to plant physiology (animal consumption is directed by the seasonal nutrient content); (iv) animal concentration or stocking density during grazing; (v) grazing duration; (vi) plant secondary compounds; and (vii) animal physiological state (Nader et al. 2007).

The use of grazing as a wildfire prevention tool can either be treated as a short-term measure to reduce flammable vegetation (type of plant species and type and amount of biomass to be eliminated: leaves? twigs? stems?) or a long term measure to change vegetation composition by depleting root carbohydrates in perennials and reducing the soil seed bank for annual plants.

The main objectives of wildfire prevention through grazing are to change fire behavior through the modification of the fuel bed, fuel loading, percent cover, and ladder fuels.

As an example, Chapman \& Reid (2004) report that in a mixed shrubland in Nevada, using a stocking density of 1.1 Animal Unit Month (AUM) per acre for 30 days in May, $73 \%$ of the forage was eaten, ground litter was reduced by about $60 \%$, and vegetation height was reduced by approximately $75 \%$. Fire experts estimated this would decrease the rate of spread of a fire by about $75 \%$ and reduce the likely height of the flames from 6' $-10^{\prime}(182-305 \mathrm{~cm})$ down to about 2' -3 ' $(61-92 \mathrm{~cm})$.

In any case, grazing for wildfire prevention requires skilled herders. Also, the problem of the social stigma attached to goats and goat herders still remains (Green \& Newell 1982). Perhaps that stigma comes from the distinctive odor of active breeding male goats (Anonymous 2012). 
Tab. 1 - Strength-weakness points of goats use in fire prevention.

\begin{tabular}{|c|c|}
\hline Strength & Weakness \\
\hline can profitably convert brush and weeds into a salable product & $\begin{array}{l}\text { cannot withstand wet weather that is accompanied by freezing or } \\
\text { near freezing temperatures }\end{array}$ \\
\hline $\begin{array}{l}\text { can be grazed with other species including cattle, sheep, or horses } \\
\text { in a co-species grazing system }\end{array}$ & $\begin{array}{l}\text { eat the bark of some tree species, effectively killing the trees by } \\
\text { girdling }\end{array}$ \\
\hline $\begin{array}{l}\text { difference in diet preference makes these classes of livestock com- } \\
\text { patible and complementary }\end{array}$ & $\begin{array}{l}\text { when forced to eat shrub species of low palatability, } \\
\text { poison plants could cause losses }\end{array}$ \\
\hline $\begin{array}{l}\text { internal parasites are reduced when cattle or horses graze with } \\
\text { goats }\end{array}$ & $\begin{array}{l}\text { need for skilled, dedicated herders with well-trained dogs to keep } \\
\text { the band together and to prevent loss }\end{array}$ \\
\hline $\begin{array}{l}\text { livestock losses from poisonous plants are reduced by co-species } \\
\text { grazing }\end{array}$ & strong psychological burden to most people who try goat herding \\
\hline $\begin{array}{l}\text { consume a wide variety of plants and select higher quality plants } \\
\text { than cattle and sheep }\end{array}$ & the social stigma of the goat herder \\
\hline resistant to many plant toxins and anti-nutritive factors & - \\
\hline $\begin{array}{l}\text { capable of defoliating most plants species, many of which cattle } \\
\text { will not utilize }\end{array}$ & - \\
\hline $\begin{array}{l}\text { while eating undesirable plants they produce a salable product } \\
\text { (milk) }\end{array}$ & - \\
\hline $\begin{array}{l}\text { preferentially consume seeding stems, reducing the spread and per- } \\
\text { petuation of weeds by seed }\end{array}$ & - \\
\hline $\begin{array}{l}\text { ticks and snakes are reduced due to reduction of their } \\
\text { habitat }\end{array}$ & - \\
\hline $\begin{array}{l}\text { opportunistic generalists, they tend to consume the most palatable } \\
\text { available vegetation }\end{array}$ & - \\
\hline very flexible in their dietary habits, able to adjust to a diet change & - \\
\hline $\begin{array}{l}\text { able to select the most nutritious available components of biomass, } \\
\text { regardless of type }\end{array}$ & - \\
\hline tolerate higher levels of tannins than cattle or sheep & - \\
\hline $\begin{array}{l}\text { in most cases, goats are the most cost-effective, nontoxic, non pol- } \\
\text { luting solution available }\end{array}$ & - \\
\hline
\end{tabular}

Goats must be confined in pens of an area of approximately 0.9 hectares which are enclosed by a traditional metal fence, electrified netting or por-wire polywire fence. An electrified fence must be energized by low impedance battery-powered fence energizers, which send a pulse of electricity through the wires, eliminating the possibility of overheating. Solar panels can be used to keep batteries charged. Predators, if any, can be discouraged by electric fencing (Correa 2012).

Goats require better fences than sheep or cattle to ensure their containment, namely sheep and goat net wire which has a wider space between the vertical stays.

In order to maximize fuel reduction, a high stock density is necessary when a complete elimination of biomass is required (Correa 2012).

Existing data indicates there are two ways in which grazing impacts the fuel load; removal of vegetation and hoof incorporation of fine fuels. Tsiouvaras et al. (1989) report that in a California Monterey pine and eucalyptus forest in the fall at a stocking rate of 113 Spanish goats per acre for 3 days, the brush understory was reduced by $46 \%$ and
$82 \%$ at 20 inches and 59 inches in height respectively.

Goat grazing not only broke up the sequence of live fuels (horizontally and vertically up to 59 inches), but also reduced the amount of 1 -hour dead fuels by $58.3 \%$, although the 100-hour fuels remained constant.

The litter depth was also reduced as much as $27.4 \%$ (from 2.9 inches before to 2 inches after grazing). Animal trampling which crushed fine fuels and mixed them into the mineral soil thus reduced the chance of ignition.

Lindler et al. (1997 in Ingram et al. 2013) reported that goats stocked at 7 per acre for 3 weeks in the summer in a ponderosa pine forest were estimated to remove $15-25 \%$ of the vegetation, depending on the plant species present and the length of stay in the pasture. The same authors reported that a stocking rate of 37 goats per hectare in a California pine forest is required to effectively treat understory brush.

The high stock density in such a small space creates many trails, which act as minifuel breaks that help break up the continuity of available fuel (Mendenhall 2004, Kirk- patrick et al. 2011, Mancilla-Leytón et al. 2012).

Dogs are a main part of the system, even though their barking may not be welcome in some areas such as in the wild land-urban interface. They help to contain livestock and move animals into and out of paddocks and into the trailers for their transport (AFP 2009).

\section{Pros and cons: a reduced SWOT}

We can summarize current knowledge about goats as wildfire prevention tools as reported in Tab. 1 (Pastor et al. 2006, Luginbuhl \& Pietrosemoli Castagni 2007, Jáuregui et al. 2009, McGinty et al. 2009, Mancilla-Leytón \& Martín Vicente 2012).

\section{Summary and conclusion}

Prescribed goat grazing has the potential to be an ecologically and economically sustainable management tool for the local reduction of fuel loads, mainly $1 \mathrm{~h}$ and $10 \mathrm{~h}$ fine dead fuels and smaller diameter live fuels. These fine dead fuels can greatly impact the rate of spread of a fire and flame height, both of which are responsible for fire propagation (Pastor et al. 2006, Nader et al. 2007, Man- 
cilla-Leytón \& Martín Vicente 2012).

Far from being a simple technique, prescribed goat grazing is more complex than simply putting a goat out to eat a plant; it requires careful evaluation of the type of animals and planning of timing. The technique also requires further research, since information about grazing for fuel reduction is anecdotal and there is only limited scientific information currently available, mainly for the Mediterranean area (Nader et al. 2007, Kirkpatrick et al. 2011).

The economically sustainable use of prescribed herbivory could be used for (Taylor 2006, Diamond et al. 2009, Hudak et al. 2011):

- maintenance grazing of fuel breaks with mixed goat-sheep flocks;

- high impact browsing where prescribed burns are not possible (high cost service);

- specialized impact browsing in timber plantations (medium/high cost service);

- follow-up on burned areas (short term).

Goats are the most cost-effective, non-toxic, non-polluting solution available; they are greatly appreciated by the general public and they are an environmentally friendly and effective method of nearly carbon-neutral weed control which deserve further attention and applied research.

\section{Acknowledgments}

The authors would like to thank dr. Robert Stacey for careful review of our manuscript and providing us with suggestion to improve its quality.

\section{References}

AFP (2009). Google fields low-tech wildfire prevention: goats. Web site. [online] URL: http://www.google.com/hostednews/afp/article/A LeqM5jilr7SJF_sk75rQzGG4PO4Zichnw

Anonymous (2012). Meat and dairy goats in cache county. Cooperative Extension, Utah State University, Logan, UT, USA, pp. 2. [online] URL: http://extension.usu.edu/files/publications/ publication/pub 6955528.pdf

Ascoli D, Catalanotti A, Valese E, Cabiddu S, De$\operatorname{logu} \mathrm{G}$, Driussi M, Esposito A, Leone V, Lovreglio R, Marchi E, Mazzoleni S, Rutigliano F, Strumia S, Bovio G (2012). Prescribed burning experiences in Italy: an integrated approach to prevent forest fires. Forest@ 9 (1): 20-38. [in Italian with English abstract] - doi: 10.3832/ efor0686-009

Ascoli D, Lonati M, Marzano R, Bovio G, Cavallero A, Lombardi G (2013). Prescribed burning and browsing to control tree encroachment in southern European heathlands. Forest Ecology and Management 289: 69-77. - doi: 10.1016/j.foreco.2012.09.041

Baraza E, Hodar JA, Zamora R (2009). Consequences of plant-chemical diversity for domestic goat food preference in Mediterranean forests. Acta Oecologica 35: 117-127. - doi: 10.1016/j. actao.2008.09.001
Beatson A (1810). Papers relating to the devastation committed by goats on the island of St. Helena, from the period of their introduction to the present time; comprising experiments, observations and hints, connected with agricultural improvement and planting. S. Solomon - J. Coupland Publishing, St. Helena, SC, USA, pp. 80 .

Birot Y (2009). Living with wildfires: what science can tell us - a contribution to the sciencepolicy dialogue. Discussion Paper 15, European Forest Institute, Joenssu, Finland, pp. 82. [online] URL: http://www.cabdirect.org/abstracts/ 20093126408.html

Blanchemain A (1981). Paturage en forêt: quel est le problème? Forêt méditerranéenne 3 (1): 69. [online] URL: http://www.foret-mediterraneen ne.org/upload/biblio/FORET_MED_1981_1_58. pdf

Bonnier J (1981). Rôle du paturage dans la prévention des incendies de forêts. Forêt méditerranéenne 3 (1): 71-72. [online] URL: http://www.foret-mediterraneenne.org/upload/bib lio/FORET MED 1981 1 58.pdf

Burgess K (2009). Goats do the yard work at Google headquarters. LA Unleashed, Los Angeles Times, 5 May 2009, Los Angeles, CA, USA. [online] URL: http://atimesblogs.latimes.com/unleashed/2009/05/goats-do-the-yard-

work-at-google-headquarters.html

Cabrero A (2009). Camp Williams using goats to fight wildfires. KSL.com, web site. [online] URL: http://www.ksl.com/?nid=148\&sid=73431 28

Cans R (1999). Toutes les forêts brûlent. Forêt méditerranéenne 20: 23-24. [online] URL: http://www.foret-mediterraneenne.org/fr/catalogue/id-565-toutes-les-forets-brulent-

Chapman CK, Reid CR (2004). Sheep and goats: ecological tools for the $21^{\text {st }}$ century. Extension AG/Sheep/2004-1, Utah State University, Logan, UT, USA, pp. 4. [online] URL: http://extension. usu.edu/files/factsheets/Sheep $\% 20$ and $\% 20$ Goats. pdf

Coffey L, Hale M, Wells A (2004). Goats: sustainable production overview. ATTRA, National Sustainable Agriculture Information Service, NCAT, Fayetteville, Arkansas, USA, pp. 24. [online] URL: http://cemendocino.ucanr.edu/files/ 131469.pdf

Calabri G (1981). Le p'turage et les incendies de forêts en Italie. Forêt méditerranéenne 3 (1): 6164. [online] URL: http://www.foret-mediterraneenne.org/upload/biblio/FORET_MED_1981_1 58.pdf

Cavara F (1914). La végétation de la Tripolitaine et l'utilisation économique et agraire de la nouvelle colonie. Naples. In: "Sand-dune fixation and afforestation in Libya" (Messines J ed). Unasylva 6: 50-58. [online] URL: http://www.fao.org/docrep/x $5363 \mathrm{e} / \mathrm{x} 5363 \mathrm{e} 02 . \mathrm{htm}$

Correa JE (2012). Grazing systems. Pub. UNP0007, Alabama Cooperative Extension System, Alabama A\&M and Auburn Universities, Montgomery, AL, USA, pp. 4. [online] URL: http:// www.aces.edu/pubs/docs/U/UNP-0007/index2.t $\mathrm{mpl}$

Costa Alcubierre P, Castellnou Ribau M, Larrañaga Otxoa de Egileor A, Miralles Bover M, Kraus PD (2011). Prevention of large wildfires using the fire types concept. EU Fire Paradox Publication, Barcelona, Spain, pp. 83. [online] URL: http://www.efi.int/files/attachments/publications/handbook-prevention-large-fires_en.pdf Deeming J, Lancester JW, Fosberg MA, Furman RW, Schroeder MJ (1972). The national firedanger rating system. Research Paper RM-84, Rocky Mountain Forest and Range Experiment Station, USDA Forest Service, Fort Collins, CO, USA, pp. 165.

Devendra C (1999). Goats: challenges for increased productivity and improved livelihoods. Outlook on Agriculture 28 (4): 215-226. [online] URL: http://www.ilri.org/InfoServ/Webpub/fulldocs/Outlk2840/Goats.htm

Diamond JM, Christopher A, Call CA, Devoe N (2009). Effects of targeted cattle grazing on fire behaviour of cheatgrass-dominated rangeland in the northern Great Basin, USA. International Journal of Wildland Fire 18: 944-950. - doi: 10.1071/WF08075

Dimanche M, Coudour R (2005). The pastoralism, partner of forest fire management: 20 years of practices in Languedoc Roussillon region. In: Proceedings of the " 2 nd International Conference on prevention strategies for fires in Southern Europe, Forest management as a tool for wildfire prevention”. Barcelona (Spain) 9-11 May 2005. Centre Tecnològic Forestal de Catalunya, Barcelona, Spain, pp. 74-75.

Du Plessis I, Van der Waal C, Webb EC (2004). A comparison of plant form and browsing height selection of four small stock breeds - preliminary results. South African Journal of Animal Science 34 (Suppl. 1): 31-34. [online] URL: http://www. boergoats.co.za/PDFfiles/Researchdocuments/Br owsingheight.pdf

EFIMED (2012). The fight against forest fires: an inconvenient truth? EFIMED Network News, Mediterranean Regional Office of the European Forest Institute, Barcelona, Spain, pp. 1. [online] URL: http://news.efi.int/newsletter/view/efimednewsletter-august-2012/1044

Fernandes PM, Botelho HS (2003). A review of prescribed burning effectiveness in fire hazard reduction. International Journal of Wildland Fire 12: 117-128 - doi: 10.1071/WF02042

Foroughbakhch R, Hernández-Piñero JL, CarrilloParra A, Rocha-Estrada X (2013). A composition and animal preference for plants used for goat feeding in semiarid northeastern Mexico. Journal of Animal and Plant Sciences 23 (4): 1034-1040. [online] URL: http://www.thejaps. org.pk/docs/v-23-4/14.pdf

Fuhlendorf SD, Archer SA, Smeins FE, Engle DM, Taylor CA (2008). The combined influence of grazing, fire, and herbaceous productivity on tree-grass interactions. In: "Western North American Juniperus Communities: A Dynamic Vegetation Type" (Van Auken OW ed). Ecological Studies Series, vol. 196, Springer, Berlin, Germany, pp. 219-238. - doi: 10.1007/978-0-387- 
34003-6_12

Georgoudis A, Rosati A, Mosconi C (2005). Animal production and natural resources utilisation in the Mediterranean mountain areas. EAAP Pub. 115, Wageningen Academic Publishers, Wageningen, The Netherlands, pp. 624. [online] URL: http://www.eaap.org/docs/Publications/ea ap115\%20-\%20665121875A.pdf

Goetsch AL, Gipson TA, Askar AR, Puchala R (2009). Feeding behavior of goats. Journal of Animal Science 88 (1): 361-373. - doi: 10.2527/ jas.2009-2332

Govtrack US (2013). S. 1479: catastrophic wildfire prevention act of 2013. Web site. [online] URL: http://www.govtrack.us/congress/bills/113/ s1479

Graham RT, McCaffrey S, Jain TB (2004). Science basis for changing forest structure to modify wildfire behavior and severity. Gen. Tech. Rep. RMRS-GTR-120, Rocky Mountain Research Station, USDA Forest Service, FortCollins, CO, USA, pp. 43. [online] URL: http://www.fs.fed.us/rm/pubs/rmrs_gtr120.pdf

Green LR, Newell LA (1982). Using goats to control brush regrowth on fuelbreaks. Gen. Tech. Rep. PSW-59, Pacific Southwest Forest and Range Experiment Station, USDA Forest Service, Albany, Ca, USA, pp. 13. [online] URL: http://www.fs.fed.us/psw/publications/document s/psw_gtr059/psw_gtr059.pdf

Guatieri G (1816). Dei vantaggi e dei danni derivanti dalle capre in confronto alle pecore [Benefits and damages resulting from the goats compared to sheep]. In: "Risorse silvo-pastorali, conflitto sociale e sistema alimentare: il ruolo della capra nelle comunità alpine della Lombardia e delle aree limitrofe in età moderna e contemporanea" (Corti M ed). SM Annali di S. Michele 19: 235-340. [in Italian] [online] URL: http://www.ruralpini.it/file/Ruralismo/Materialiruralisti/Risorse_silvo_pastorali_conflitto_sociale e sistema alimentare.pdf

Hagstrom K, Christiansen ML, Cleveland ER (1993). Plants in Hawaii that are eaten by goats. Journal of Hawaian and Pacific Agriculture 4 101-105.

Haenlein GFW, Caccese R, Sammelwitz PH (1992). Behavior. In: "National Goat Handbook". National Dairy Database, National Agricultural Library, University of Maryland, MD, USA, pp. 412. [online] URL: http://outlands.tripod.com/farm/national_goat_handbook.pdf Harrington TB (2012). Silvicultural basis for thinning southern pines: concepts and expected responses. Georgia Forestry Commission, Warnell School of Forest Resources, University of Georgia, Athens, GA, USA, pp. 20. [online] URL: http://www.gfc.state.ga.us/resources/publications /SilviculturalApproaches.pdf

Harris S (2007). Colonial forestry and environmental history: British policies in Cyprus, 18781960. PhD Thesis, University of Texas, Austin, TX, USA, pp. 504. [online] URL: http://repositories.lib.utexas.edu/bitstream/handle/2152/

Harris SE (2012). Cyprus as a degraded landscape or resilient environment in the wake of colonial intrusion. Proceedings of the National Academy of Sciences USA 109 (10): 3670-3675. - doi: 10.1073/pnas. 1114085109

Hart S (2001). Recent perspectives in using goats for vegetation management in the USA. Journal of Dairy Science 84: E170-E176. - doi: 10.3168/ jds.S0022-0302(01)70212-3

Hudak AT, Rickert I, Morgan P, Strand E, Lewis SA, Robichaud PR, Hoffman C, Holden ZA (2011). Review of fuel treatment effectiveness in forests and rangelands and a case study from the 2007 megafires in central Idaho, USA. Gen. Tech. Rep. RMRS-GTR-252, Rocky Mountain Research Station, USDA Forest Service, Fort Collins, CO, USA, pp. 60. [online] URL: http://www.fs.fed.us/rm/pubs/rmrs gtr252.pdf

Hutchens T (2003). Kentucky goat friendly pasture concept. Goat Producer's Newsletter, Cooperative Extension Service, Kentucky University, October-November 2003, pp. 1-4.

Ingram RS, Doran MP, Nader G (2013). Planned herbivory in the management of wildfire fuels. In: "Herbivory" (Barros B, Fernandes MEB eds). InTech, Rijeka, Croatia, pp. 76. [online] URL: http://www.intechopen.com/books/herbivory

Kazuki (2009). Google is hiring (weed consumer wanted?). Kazuki Presents, web site. [online] URL: http://kipre.wordpress.com/2009/05/14/go ogle-is-hiring-weed-consumer-wanted/

Kirkpatrick JB, Marsden-Smedley JB, Leonard SWJ (2011). Influence of grazing and vegetation type on post-fire flammability. Journal of Applied Ecology 48 (3): 642-649. - doi: 10.1111/ j.1365-2664.2011.01962.x

Knapp EE, Estes BL, Skinner CN (2009). Ecological effects of prescribed fire season: a literature review and synthesis for managers. Gen. Tech. Rep. PSW-GTR-224, Pacific Southwest Research Station, USDA Forest Service, Albany, CA, USA, pp. 80. [online] URL: http://www. treesearch.fs.fed.us/pubs/33628

Jáuregui BM, García U, Osoro K, Celaya $\mathrm{R}$ (2009). Sheep and goat grazing effects on three atlantic heathland types. Rangeland Ecology and Management 62 (2) 119-126. - doi: 10.2111/07120.1

Launchbaugh K, Walker J (2006). Targeted grazing - a new paradigm for livestock management. In: "Targeted grazing: a natural approach to vegetation management and landscape enhancement" (Launchbaugh K ed). American Sheep Industry Association - ASI, Washington, DC, USA, pp. 8. [online] URL: http://www. cnr.uidaho.edu/rx-grazing/handbook/Chapter_1_ Targeted_Grazing.pdf

Leone V (2002). Forest management: pre and post fire practices. In: "Fire, Landscape and Biodiversity: An Appraisal of the Effects and Effectiveness" (Pardini, G, Pintó, J eds). Diversitas, Universitat de Girona, Spain, pp. 117-141.

Leone V, Saracino A, Trabaud L, Velez R (2000). Fire management and prevention policies in west Mediterranean pine forests. In: "Ecology, Biogeography and Management of Mediterranean Pine Forest Ecosystems (Pinus halepensis and $P$. brutia)" (Ne'eman G, Trabaud L eds). Backhuys
Publishers, The Hague, The Netherlands, pp 335-354.

Leone V, Signorile A, Gouma V, Pangas N, Chronopoulou-Sereli A (1999). Obstacles in prescribed fire use in Mediterranean countries: early remarks and results of the Fire Torch project. In: Proceedings of the "DELFI International Symposium. Forest Fires: Needs and Innovations". Athens (Greece) 18-19 Nov 1999. CINAR SA, Athens, Greece, pp. 132-136.

Lipson J, Reynolds T, Anderson L (2011). Environmental implications of livestock series: goats. EPAR Brief No. 156, Evans School of Public Affairs, University of Washington, Seattle, WA , USA, pp. 14. [online] URL: http://evans.washington.edu/files/EVANS UW Request 156 Environmental_Impacts_of_Livestock_Goats_0.pdf Lopez-Trujillo R, Garcia-Elizondo R (1995). Botanical composition and diet quality of goats grazing natural and grass reseeded shrublands. Small Ruminant Research 16 (1): 37-47. - doi: 10.1016/0921-4488(94)00046-A

Lu CD (1988). Grazing behavior and diet selection of goats. Small Ruminant Research 1: 205 216. - doi: 10.1016/0921-4488(88)90049-1

Luginbuhl JM (2000). Pasture for meat goats. Langston University, Langston, OK, USA, pp. 39. [online] URL: http://www.luresext.edu/goats/ training/pastures.pdf

Luginbuhl JM, Pietrosemoli Castagni S (2007). Utilización de caprinos para el control de vegetación indeseable - Use of goats to control undesirable vegetation. Arch Latinoam Prod Anim 15 (Suppl. 1): 294-309. [online] URL: http://www.bioline.org.br/request?la07067

Mancilla-Leytón JM, Pino Mejías R, Martín Vicente A (2012). Do goats preserve the forest? Evaluating the effects of grazing goats on combustible Mediterranean scrub. Applied Vegetation Science 16 (1): 63-73. - doi: 10.1111/j.1654 -109X.2012.01214.X

Mancilla-Leytón JM, Martín Vicente A (2012). Biological fire prevention method: Evaluating the effects of goat grazing on the fire-prone Mediterranean scrub. Forest Systems 21 (2): 199-204. - doi: 10.5424/fs/2012212-02289

McGinty EL, Baldwin B, Banner R (2009). A review of livestock grazing and range management in Utah. Utah State University, Salt Lake City, UT, USA, pp. 45. [online] URL: http://www. learningace.com/doc/2165345/7fdadba86552b88 f32971d1d7c426776/literature_review

Mendenhall M (2004). Fighting fire with goats at Camp Williams. Utah Forest News, Utah Forest Landowner Education Program Newsletter 4: 45. [online] URL: http://forestry.usu.edu/files/uploads/UFN0804.pdf

Messines J (1952). Sand-dune fixation and afforestation in Libya. Unasylva 6 (2): 50-58. [online] URL: http://www.fao.org/docrep/x5363e/x5363e 02.htm

Molina D, Castellnou M, García-Marco D, Salgueiro A (2010). Improving fire management success through fire behaviour specialists. In: "Towards Integrated Fire Management Outcomes of the European Project Fire Paradox" (Silva JS, 
Rego F, Fernandes P, Rigolot E eds). Research Report 23, European Forest Institute, Joensuu, Finland, pp. 105-119. [online] URL: http://www. efi.int/portal/virtual_library/publications/research_reports/23

Montiel C, Herrero G (2010). An overview of policies and practices related to fire ignitions at the European Union level. In: "Towards integrated fire management-outcomes of the european project fire paradox" (Silva JS, Rego F, Fernandes P, Rigolot E eds). Research Report 23, European Forest Institute, Joensuu, Finland, pp. 35-46. [online] URL: http://www.efi.int/portal/virtual library/publications/research_reports/23

Moser PM (2006). Regeneration and utilization of Faidherbia albida and Acacia erioloba along ephemeral rivers of Namibia. In: "Ecology and Development" (Denich M, Martius C, Rodgers C eds). Series No. 42, Cuvillier Verlag, Göttingen, Germany, pp. 122. [online] URL: http://www.zef.de/fileadmin/webfiles/downloads/zefc_ecology _development/ecol_dev_42_text.pdf

Nader G, Henkin Z, Smith E, Ingram R, Narvaez $N$ (2007). Planned herbivory in the management of wildfire fuels. Rangelands 29: 18-24. - doi: 10.2111/1551-501X(2007)29[18:PHITMO]2.0. $\mathrm{CO} ; 2$

Nastis AS (1997). Feeding behaviour of goats and utilsation of pasture and rangelands. In: "Recent advances in goat research" (Moran D, Fehr P eds). Cahiers Options Méditerranéennes 25: 39 45.

Nastis AS, Nolan T (1997). Some aspects of the use of vegetation by grazing sheep and goats. In: "Recent advances in small ruminant nutrition" (Lindberg JE, Gonda HL, Ledin I eds). Options Méditerranéennes, Série A, Séminaires Méditerranéens, vol. 34, pp. 11-25.

Omi PN, Martinson EJ (2002). Effects of fuels treatment on wildfire severity. Final report, Joint Fire Science Program Governing Board, Western Forest Fire Research Center, Colorado State University, Fort Collins, CO, USA, pp. 40. [online] URL: http:/www.ntc.blm.gov/krc/uploads/399/ Effects $\% 20$ of $\% 20$ Fuels $\% 20$ Treatment $\% 20$ on $\% 2$ 0Wildfire\%20Severity.pdf

Omi PN, Joyce LA (2003). Fire, fuel treatments, and ecological restoration. Tec. Rep. RMRS-P29, Rocky Mountain Research Station, USDA Forest Servce, Fort Collins, CO, USA, pp. 475. [online] URL: http://www.fs.fed.us/rm/pubs/rm rs_p029.pdf

Otero I (2010). Matadepera, Barcelona metropoli$\tan$ region. Peasant Memory for Wildfire Prevention, Spain, pp. 10. [online] URL: http://www. uclg-cisdp.org/sites/default/files/Matadepera 20 10_en_final.pdf

Papanastasis VP (1986). Intégrer la chèvre à la forêt méditerranéenne . Unasylva 38: 44-52. [in French] [online] URL: http://www.fao.org/do crep/50630F/50630f06.htm

Papanastasis VP (2000). Land degradation caused by overgrazing and wildfires and management strategies to prevent and mitigate their effects. In: "EUR 19390 desertification in Europe: mitigation strategies, land-use planning" (Enne G,
Zanolla C, Peter D eds). Advanced study course, Office for Official Publications of the European Communities, Luxembourg, pp. 509. [ISBN 92828-9003-1]

Papanastasis VP (2004). Grazing lands and pastoral landscapes. LUCINDA (Land Care in Desertification Affected Areas: From Science towards Application), Booklet 5, n.5, pp. 40. [online] URL: http://geografia.fcsh.unl.pt/lucinda/ booklets/Booklet $\% 20$ C5\%20EN.pdf

Papachristou T (1997). Foraging behaviour of goats and sheep on Mediterranean kermes oak shrublands. Small Ruminant Research 24 (2): 85-93. - doi: 10.1016/S0921-4488(96)00942-X

Pastor E, Pérez Y, Miralles M, Nebot E, Plana E (2006). Prescribed burning in Catalonia: fire management and research. In: Proceedings of the " $10^{\text {th }}$ Biennial Australasian Bushfire Conference 2006". Brisbane (Australia) 6-9 June 2006. Paper No. 39300039, Griffith University, Brisbane, Australia, pp. 5. [online] URL: http://search.informit.com.au/documentSummary; $\mathrm{dn}=58811913$ 9626721;res=IELHSS

Pittroff W, Narvaez N, Ingram R, Barry S, Nader G, Morgan Doran M (2006). Prescribed herbivory for fire fuels management. In: Proceedings of the Symposium "Society for Range Management" (Barry S, Risberg D). San Jose (CA, USA), 23 June 2006. California-Pacific Section Society for Range Management, University of California Cooperative Extension, San Jose, CA, USA, pp. 2. [online] URL: http://ucanr.org/sites/ sccNew/files/51858.pdf

Pollet J, Omi PN (2002). Effect of thinning and prescribed burning on crown fire severity in ponderosa pine forests. International Journal of Wildland Fire 11: 1-10. - doi: 10.1071/WF01045 Rego F, Montiel C (2010). Lessons learned and the way ahead. In: "Best practices of fire use prescribed burning and suppression fire programmes in selected case-study regions in Europe" (Montiel C, Krauss D eds). Research Report 24, European Forest Research Institute, Joensuu, Finland, pp. 165-169. [online] URL: http://www.efi.int/portal/virtual_library/publications/research_reports/24/

Ruiz-Mirazo J (2011). Environmental benefits of extensive livestock farming: wildfire prevention and beyond. Options Méditerranéennes 100: 7582. [online] URL: http://ressources.ciheam.org/ om/pdf/a100/00801486.pdf

Ruiz-Mirazo J, Robles AB, González-Rebollar JL (2009). Pastoralism in natural parks of Andalucía (Spain): a tool for fire prevention and the naturalization of ecosystems. In: "Changes in sheep and goat farming systems at the beginning of the 21st century" (Pacheco F, Morand-Fehr P ds). CIHEAM-IAMZ, Zaragoza, Options Méditerranéennes, Série A, Séminaires Méditerranéens 91: 141-14. [online] URL: http://digital.csic.es/bitstream/10261/42929/1/OPTIONS_p ontedelima descargado.pdf

Ruiz-Mirazo J, Robles AB (2012). Impact of targeted sheep grazing on herbage and holm oak saplings in a silvopastoral wildfire prevention system in south-eastern Spain. Agroforestry Sys- tems 86 (3): 477-491. - doi: 10.1007/s10457012-9510-z

Seigue A (1985). La forêt circumméditerranéenne et ses problèmes. Collection Rechniques Agricoles et Productions Méditerranéennes no. 5, Maisonneuve et Larose, Paris, France, pp. 502.

Scott JH, Reinhardt ED (2001). Assessing crown fire potential by linking models of surface and crown fire behavior. Research Paper RMRS-RP29, Rocky Mountain Research Station, USDA Forest Service, Fort Collins, CO, USA, pp. 59. [online] URL: http://www.treesearch.fs.fed.us/ pubs/4623

Siddle D (2009). Goats, marginality and the dangerous other. Environment and History 15 (4): 521-536. - doi: 10.3197/096734009X12532652 872117

SRCD (2006). Grazing handbook a guide for resource managers in coastal California. Sotoyome Resource Conservation District, Pistil Books Online, Seattle, WA, USA, pp. 68. [online] URL: http://www.carangeland.org/images/GrazingHan dbook.pdf

Taylor CA (2006). Targeted grazing to manage fire risk. In: "Targeted grazing: a natural approach to vegetation management and landscape enhancement" (Launchbaugh K ed). American Sheep Industry Association - ASI, Washington, DC, USA, pp. 108-114. [online] URL: http:// www.cnr.uidaho.edu/rx-grazing/Handbook/Chap ter 12 Targeted_Grazing.pdf

Thirgood JV (1981). Man and the Mediterranean forest. A history of resource depletion. Academic Press, London, UK, pp. 194.

Tsiouvaras CN, Havlik NA, Bartolome JW (1989). Effects of goats on understory vegetation and fire hazard reduction in a coastal forest in California. Forest Science 35: 1125-1131.

USDA (2013). Goat grazing for fuels reductionon the Cleveland National Forests. Blog, posted June 19. [online] URL: http://blogs.usda.gov/ 2013/06/19/goats-grazing-for-fuels-reduction-on -the-cleveland-national-forest/

Vélez R (2010). Prescribed burning for improved grazing and social fire prevention: the Spanish EPRIF Program. In: "Best practices of fire use prescribed burning and suppression fire programmes in selected case-study regions in Europe" (Montiel C, Krauss D eds). Research Report 24, European Forest Research Institute, Joensuu, Finland, pp. 117-122. [online] URL: http://www.efi.int/portal/virtual_library/publications/research_reports/24/

Vélez R (1990). Preventing forest fires through sylviculture. Unasylva 162 (41): 10-12. [online] URL: http://www.fao.org/docrep/t9500E/t9500e 03.htm

Von Maydell HJ (1980a). Effects of goat husbandry on forest and range ecosystems. Journal of Plant Research and Development 12: 98-108. [online] URL: http://www.cabdirect.org/abstra cts/19810720725.html

Von Maydell HJ (1980b). Forstwirtschaft und Ziegenhaltung - Aufgaben im Rahmen der Waldweidewirtschaft [Forestry and goat keeping: suggestions for sylvo-pastoral management]. For- 
starchiv 51 (4): 72-77. [online] URL: http:// www.cabdirect.org/abstracts/19800663734.html Voth K (2009). Prevent or reduce fire with goats: no kidding! Joint Fire Science Program, Fire Science Brief 34: 1-6. [online] URL: http://www. firescience.gov/projects/briefs/99-1-3-02 FS-

Brief34.pdf

Walker JW (1994). Multispecies grazing: the eco- logical advantage. Sheep Research Journal (1994): 52-64. [online] URL: http://www.sheepusa.org/?page=site/get_file\&file_id $=1$ e $7303 \mathrm{~d} 8$ c895d2d15c8ae19fb6abd2a1

Xanthopoulos G, Caballero D, Galante M, Alexandrian D, Rigolot E, Marzano R (2006). Forest Fuels Management in Europe. In: Proceedings of the "Fuels Management'How to Measure Suc- cess" (Andrews PL, Butler BW eds). Portland (OR - USA) 28-30 March 2006. RMRS-P-41, Rocky Mountain Research Station, USDA Forest Service, Fort Collins, CO, USA, pp. 29-36. [online] URL: http://www.fs.fed.us/rm/pubs/rmrs p041/rmrs_p041_029_046.pdf 